\title{
Applying Humanitarian Law: A Review of the Legal Status of the Turkey-Kurdistan Workers' Party (PKK) Conflict
}

\author{
Deniz Arbet Nejbir \\ School of Law, Queen's University Belfast, Belfast, UK \\ dnejbiroı@qub.ac.uk
}

\begin{abstract}
This article assesses the applicability of the criteria for non-international armed conflict to the situation in South-Eastern Turkey. It demonstrates that the Kurdistan Workers' Party (also known as the PKK), as a party to the conflict, fulfils the three main criteria laid down in conventional international humanitarian law and developed by indicative factors in international jurisprudence for assessing the existence of a non-international armed conflict in the context of Common Article 3 to the 1949 Geneva Conventions: being an organised armed group, having the ability to engage in 'protracted violence', and complying with law of armed conflict. It establishes that the PKK qualifies as an organised armed group under responsible command and has the operational ability, structure and capacity to carry out 'protracted violence', to respect fundamental humanitarian norms of international humanitarian law and to control territory. The article also ascertains that Turkey is clearly bound by the provisions of the four Geneva Conventions of 1949, including Common Article 3, and customary international humanitarian law. Accordingly, it concludes that the conflict between the PKK and the Turkish security forces qualifies as a non-international armed conflict within the meaning of both Common Article 3 and customary international humanitarian law.
\end{abstract}

\section{Keywords}

PKK - Kurds - Turkey - Common Article 3- non-international armed conflict 
Prior to the mid-twentieth century, international humanitarian law (' $\mathrm{HHL}$ ') dealt exclusively with armed conflict between States. This reflected the understanding that 'the initiation and waging of war was an exercise of sovereign power, a prerogative held by State, suitable for regulation by international law'. ${ }^{1}$ Therefore, apart from the consensual recognition of belligerency which was rapidly becoming obsolete, non-international armed conflicts ('NIAC s') were considered as being exclusively domestic affairs and therefore strictly regarded as beyond the scope of international regulations. ${ }^{2}$ However, IHL has considerably extended to cover situations of NIAC s since 1949. The International Criminal Tribunal for Yugoslavia ('ICTY') Appeals Chamber in the Tadić Jurisdiction Decision recapitulated four reasons for this historical evolution: the necessity for regulation and protection systems given the rising frequency of internal conflicts, the changing nature of those conflicts (protracted), and the rising involvement of third States and use of proxies. No less significant is the shift brought about by the adoption of the Universal Declaration of Human Rights ('UDHR'), whereby 'a state sovereignty approach has been gradually supplanted by a human-being-oriented approach.' ${ }^{3}$

States, in response to the Second World War and the Nazi horror, agreed to adopt Common Article 3 ('CA3') in 1949 and thereby extended the scope of I H L to NIAC s. ${ }^{4} \mathrm{CA}_{3}$ remains revolutionary in content for being the first universally

International Committee of the Red Cross ('ICRC'), 'Conflicts Not of an International Character' in ICRC (ed), Commentary on the Second Geneva Convention: Convention (II) for the Amelioration of the Condition of Wounded, Sick and Shipwrecked Members of Armed Forces at Sea (CUP 2017) 134-336, [379].

2 Hans-Peter Gasser, 'International Humanitarian Law' in Hans Haug et al (eds), Humanity for All: The International Red Cross and Red Crescent Movement (Haupt 1993) 491, 559; Lindsay Moir, The Law of Internal Armed Conflict (CUP 2002) 20.

3 Prosecutor $v$ Tadić (Decision on the Defence Motion for Interlocutory Appeal on Jurisdiction) ICTY T-94-1-AR72 (2 October 1995) [97]. See Common Article 3 to Geneva Convention for the Amelioration of the Condition of the Wounded and Sick in Armed Forces in the Field (adopted 12 August 1949, entered into force 21 October 1950) 75 UNTS 31 (First Geneva Convention); Geneva Convention for the Amelioration of the Condition of Wounded, Sick and Shipwrecked Members of Armed Forces at Sea (adopted 12 August 1949, entered into force 21 October 1950) 75 UNTS 85 (Second Geneva Convention); Geneva Convention Relative to the Treatment of Prisoners of War (adopted 12 August 1949, entered into force 21 October 1950) 75 UNTS 135 (Third Geneva Convention); Geneva Convention Relative to the Protection of Civilian Persons in Time of War (adopted 12 August 1949, entered into force 21 October 1950) 75 UNTS 287 (Fourth Geneva Convention); Theodor Meron, The Humanisation of International Law (Nijhoff 2006); Joyce Ada Cooke Gutteridge, 'The Geneva Conventions of 1949' (1949) 26 British Yearbook of International Law 294, 300. 
accepted treaty provision which regulates NIAC s, 'what was at time considered by States as being exclusively their domestic affairs.' ${ }^{5}$ The provisions of CA3 are identical in the four Geneva Conventions and endeavour to impose fundamental humanitarian principles codified in the context of interstate wars to NIAC s. ${ }^{6}$ Therefore, $\mathrm{CA}_{3}$ has been recognised as a humanitarian convention in miniature' 7 and a reflection of 'elementary considerations of humanity'. However, the vagueness of the wording of $\mathrm{CA}_{3}$ and its narrow context was not sufficient to fulfil its purpose when the catastrophes of human suffering as the result of NIAC s were taken into account. ${ }^{9}$ While interstate wars were in a state of decline, the rates of non-international armed conflicts sharply increased between the Second World War to 1977. According to the statistics, during that time-period, eighty percent of the deaths in armed conflict occurred during NIAC s. ${ }^{10}$ This demonstrates the need for more effective legal regulation for NIAC s. Based on these and other elements, governments and International Committee of the Red Cross ('ICRC') experts agreed on an urgent need to strengthen and develop IHL in relation to NIAC s with the aim of reducing the scale of human suffering."1 These concerns led to the adoption of Additional Protocol II of 1977 ('AP II') to the 1949 Geneva Conventions, which remains the only I HL treaty exclusively devoted to NIAC s. ${ }^{12}$ According to Georges Abi-Saab, the Protocol provides a:

$5 \quad \operatorname{ICRC}(\mathrm{n} 1)$ [373].

$6 \quad$ ibid; Moir (n 2) 31.

7 Georges Abi-Saab, 'Non-international Armed Conflicts' in Unesco, International Dimensions of Humanitarian Law (Nijhoff 1988) 217, 221; G I A D Draper, 'Humanitarian Law and Internal Armed Conflicts' (1983) 13 Georgia Journal of International \& Comparative Law 253, 264 .

$8 \quad$ Military and Paramilitary Activities in and against Nicaragua (Nicaragua $v$ United States) (Merits) [1986] ICJ Rep 14, [218]-[219].

9 David P Forsythe, 'Legal Management of Internal War: The 1977 Protocol on NonInternational Armed Conflict' (1978) 72(2) American Journal of International Law 272, 293-4; Moir (n 2) 67 .

See, for example, the statement by the delegate of the Federal Republic of Germany, quoting Red Cross sources, at Official Records of the Diplomatic Conference on the Reaffirmation and Development of International Humanitarian Law Applicable in Armed Conflicts, Geneva (1974-1977) (1978) vol III CDDH/I/sR.23, 10 ('Official Records'). According to a Soviet delegate, the figure should be $90 \%$ : ibid, $\mathrm{CDDH} / \mathrm{I} / \mathrm{sR} .34,16$. ibid, CDDH/I/SR.22, 201; Forsythe (n 9) 277-79; Anthony Cullen, The Concept of NonInternational Armed Conflict in International Humanitarian Law (CUP 2010) 86. Protection of Victims of Non-International Armed Conflicts (adopted 8 June 1977, entered into force 7 December 1978) 1125 UNTS 609 (AP II). 
much greater, and greatly needed, elaboration of the elliptic declarations of principle of Common Article 3, and through introducing new fundamental rules concerning the protection of civilians against the effects of hostilities [such as collective punishment, terrorism, slavery, pillage, rape enforced prostitution, indecent assault and detailed protection afforded to children], as well as the protection of medical personnel and transports. ${ }^{13}$

The application of these two main bodies of IHL rules that regulate NIAC S, either by individual application of $\mathrm{CA}_{3}$ or combined application of $\mathrm{CA}_{3}$ and AP II, had no immediate effect whatsoever on the legal status of parties to NIAC s under international law. ${ }^{14}$ Insurgents, as members of a non-State armed group in NIACs, unlike in the case of Geneva Convention III which grants prisoner-of-war status to rebellions, remain subject to domestic laws of their national State..$^{15} \mathrm{~A}$ core problem in the life of NIAC $\mathrm{s}$ has arisen from the fact that, in practice, States have proven reluctant to recognise the existence of NIAC within their territory due to fear that such acknowledgment would increase the authority of the insurgent forces and their recognition as legitimate fighters. This can be seen from a series of examples, including: France in relation to the Algeria conflict in 1955; the United Kingdom in relation to the Kenya conflict in $1955^{-58}$; by Portugal in relation to the Mozambique conflict in 1971-74; by Lebanon in the 1975-present conflict; and by Thailand in the 197375 conflict. ${ }^{16}$ In addition, the lack of a neutral decision-maker - short of the International Court of Justice ('ICJ') or International Criminal Court ('ICC') to authoritatively decide on the application of IHL and, as consequence, identify or classify a situation of armed conflict, leaves significant room for States to take advantage of non-recognition of the NIAC within their territory. This is a fundamental problem in the effectiveness of the NIAC, and one experienced in this case study of hostilities between the Kurdistan Workers' Party ('PKK') and the Turkish security forces in spite of prolonged evidence of the applicability of IHL.

Turkey has likewise denied the existence of a NIAC within its territory despite prolonged military clashes between the PKK and the Turkish security forces since 1984 either side of a series of ceasefires (20 March 1993 to 20 May

Abi-Saab (n 7) 236.

See the last sentence of $\mathrm{CA}_{3}$ : 'The application of the preceding provisions shall not affect the legal status of the Parties to the conflict'.

ICRC (n 1) [413].

Forsythe (n 9) 275-7; Cullen (n 11) 55; Moir (n 2) 67-88. 
1993; 1 September 1999 to 1 June 2004; May 2009 to May 2010; and 21 March 2013 to 22 July 2015). ${ }^{17}$ Turkey defines the actions of the PKK as 'terrorist' and defines its operations against the PKK in the Kurdish region as anti-terrorist action rather than armed conflict. In doing so, Turkey prioritises its own counter-terrorism and national security legal regime rather than IHL, and the denial of recognition of the PKK as an organised armed group under $\mathrm{CA}_{3}$ and customary international law ('CIL') helps to prevent the involvement of the international community and the conferment of undue legitimacy to the PKK. ${ }^{18}$ Similarly, international institutions (and particularly inter-governmental bodies), as far as the hostilities between the PKK and Turkish State forces are concerned, have been reluctant to express the view that the hostilities have fulfilled the criteria of NIAC. Rather, they have followed Turkey and proscribed the PKK as a 'terrorist' organisation through the executive's administrative list without any judicial overview. ${ }^{19}$

However, recent judgments of the European Court of Human Rights ('ECtHR'), ${ }^{20}$ the European Court of Justice ('ECJ') ${ }^{21}$ and the Brussels Court of Appeal ${ }^{22}$ have provided an indication that the conflict between the PKK and the Turkish security forces has met the criteria of NIAC. These decisions, apart from a brief analysis by the Brussels Court of Appeal, have not explained why the PKK is not a 'terrorist' organisation and why non-international armed

'Gecmisten Bugune PKK Ateskesleri' (CNNTurk, 28 June 2010) <www.cnnturk.com/2010/ turkiye/o6/28/gecmisten.bugune.pkk.ateskesleri/581570.o/index.html〉; 'PKK'den 20 Eylul'e Kadar Eylemsizlik Karari' (Bianet, 12 August 2010) < bianet.org/bianet/siyaset/124142pkkden-2o-eylule-kadar-eylemsizlik-karari>; Serxwebûn, '15 Agustos Direnis ve Saldiri Ruhunu Selamliyouruz!' (sayi 32, Agustos 1984) 1-2.

18 Letter from Ambassador Turkekul Kurttekn in Response to the Characterization of the PKK, Landmine Monitor Report (15 December 2005); Theodor Meron, 'The Humanization of Humanitarian Law' (2000) 94 American Journal of International Law 239, 272; Kerim Yildiz and Susan Breau, The Kurdish Conflict: International Humanitarian Law and PostConflict Mechanism (Routledge 2010) 228-9.

At the European Union level, see Council of the European Union, Council Regulation (EC) on specific restrictive measures directed against certain persons and entities with a view to combating terrorism (27 December 2001) No 2580/2001, 70; Council of the European Union, Council Decision establishing the list provided for in Article 2(3) of Council Regulation (EC) No. 2580/2001 on specific restrictive measures directed against certain persons and entities with a view to combating terrorism (27 December 2001) 2001/927/EC, 83; the United States Government has designated the PKK as a 'Foreign Terrorist Organisation' under section 219 of the United States Immigration and Nationality Act 1965 and also a 'Specially Designated Global Terrorist' under Executive Order No 13224. Benzer and Others v Turkey (Application) [2013] EC HR 23502/o6 (2 September 2014). Kurdistan Workers' Party (PKK) v Council of the European Union [2018] ECJ T-316/14 (15 November 2018). 
conflict is applicable to the conflict between the PKK and the Turkish security forces.

Seeking to contribute this debate, this article demonstrates that the hostilities between the PKK and Turkey's security forces since 1984 have met the relevant threshold criteria of NIAC under IHL. It argues that the conflict between the PKK and the Turkish security forces has fulfilled the requirement of NIAC within the meaning of $\mathrm{CA}_{3}$ and CIL. In order to establish this, this article first analyses the regulation of NIAC S under IHL. The application of IHL to the conflict in the Kurdish region of Turkey will then be elaborated on, demonstrating that Turkey is legally bound by the provisions of the Geneva Conventions and CIL. Finally, it establishes that the PKK has fulfilled the three main criteria laid down in IHL treaty law and developed by indicative factors in international jurisprudence for assessing the existence of a non-international armed conflict in the context of $\mathrm{CA}_{3}$ to the 1949 Geneva Conventions: being an organised armed group, having the ability to engage in 'protracted violence' and comply with law of armed conflict. This part also demonstrates that the PKK was able to exercise control over territory, which although not determinative, is nonetheless one possible indicator of the existence of a NIAC under $\mathrm{CA}_{3}$.

\section{Rules Regulating Non-International Armed Conflict}

Rules regulating NIAC s have developed through two separate but interrelated strands of law: first, through treaty law by adoption of $\mathrm{CA}_{3}$ and AP II; and secondly, through customary $\mathrm{IHL} .{ }^{23}$ The treaty provisions, however, failed to provide a definition of a NIAC, opting instead to set out prescriptive criteria. ${ }^{24}$

$\mathrm{CA}_{3}$ to the four Geneva Conventions of 1949 was the first substantive provision of IHL specifically governing NIAC s. ${ }^{25}$ This provision attempts to impose basic humanitarian principles contained in all four Geneva Conventions upon the parties of NIAC s. CA3 only applies 'in the case of armed conflict not of an international character occurring in the territory of one of the High Contracting Parties', and binds 'each Party to the conflict.'. ${ }^{26} \mathrm{~A}$ more restrictive approach as

$23 \quad$ Moir (n 2) 137-8.

24 Moir (n 2) 42; J G Stewart, 'Toward a Single Definition of Armed Conflict in International Humanitarian law: A Critique of Internationalized Armed Conflict' (2003) 85 International Review of the Red Cross 313, 318.

25 Cullen (n 11) 25.

26 See Common Article 3 (n 4). See also Antonio Cassese, 'The Status of Rebels Under the 1977 Geneva Protocol on Non-international Armed Conflicts' (1981) 30 International \& Comparative Law Quarterly 416, 424. 
adopted by AP II which complements the rules of $\mathrm{CA}_{3}$ with a more developed protection framework to limit suffering during NIAC s. The core difference, as will be demonstrated below, rests on the level of organisation and the ability to exercise control over territory. Article 1(1) of the Protocol applies to an armed conflict that takes place in the territory of a High Contracting Party:

between its armed forces and dissident armed forces or other organised armed groups which, under responsible command, exercise such control over a part of its territory as to enable them to carry out sustained and concerted military operations and to implement this Protocol. ${ }^{27}$

It was only in 1995 that the 'most authoritative' definition of a NIAC falling under $\mathrm{CA}_{3}$ was encapsulated by the Appeals Chamber of the ICTY. The court assessed whether the conflict in Yugoslavia constituted a NIAC in the Decision on the Defence Motion for Interlocutory Appeal on Jurisdiction in Tadić. According to the Appeals Chamber:

[A]n armed conflict exists whenever there is a resort to armed force between States or protracted armed violence between the governmental authorities and organised armed groups or between such groups within a State. ${ }^{28}$

This test, as stated by the Tadić Trial Chamber, 'focusses on two aspects of a conflict: [namely,] the intensity of the conflict and the organisation of the parties. ${ }^{29}$ These two criteria had been recognised as the core elements of a definition of NIAC 'decades and centuries earlier. ${ }^{30}$ The Tadić test has been widely adopted in the subsequent case law of the ICTY, ${ }^{31}$ the International Criminal Tribunal for Rwanda ('ICTR'), ${ }^{32}$ the ICJ ${ }^{33}$ and the ICC. ${ }^{34}$

\footnotetext{
27 See AP II (n 12) art 1(1).

$28 \quad$ Tadić (Interlocutory Appeal on Jurisdiction) (n 3) [70].

29 Prosecutorv Tadić (Trial Chamber Judgment) [1994] ICTY IT-94-1-AR73 (7 May 1997) [562].

$30 \quad$ Sandesh Sivakumaran, The Law of Non-International Armed Conflict (oup 2012) 166.

$31 \quad$ Tadić (Judgment) (n 29) [561]-[568]; Prosecutor v Delalic, Mucic and Landzo [1996] ICTY IT-96-21-T (16 November 1998) [183].

32 Prosecutorv Akayesu [1996] ICT R-96-4-T (2 September 1988) [619]; Prosecutor v Rutaganda [1996] ICT R-96-3 (6 December 1999) [91].

33 See Separate Opinion of Judge Simma in Armed Activities on the Territory of the Congo (Democratic Republic of Congo v Uganda) [2005] ICJ Rep 168, 334 [23].

34 Prosecutorv Lubanga [2004] ICC-01/04-01/o6 (29 January 2007) [233].
} 
Many scholars have argued that the Tadic test would not be applicable in those cases which fall under the scope of AP II, due to the fact that the threshold for an organisation requirement under the Protocol is higher than that required by $\mathrm{CA}_{3} \cdot{ }^{35}$ This prevailing view is confirmed by the Boškoski Trial Chamber which stated that 'the degree of organisation required to engage in "protracted violence" [under $\mathrm{CA}_{3}$ ] is lower than the degree of organisation required to carry out "sustained and concerted military operations" under AP II' ${ }^{36}$ According to the Trial Chamber, this difference is logical considering that the more detailed rules of IHL, in contrast to conflict within the context of $\mathrm{CA}_{3}$, apply in AP II conflicts, during which an organised armed group must exercise territorial control in order to be 'capable of effectively applying the rules of the Protocol:. ${ }^{37}$

The question arises whether the same degree of violence is required according to the $\mathrm{CA}_{3}$ and AP II rubrics. Cullen described that AP II's requirement of sustained and concerted military operations is '[p] erhaps the most significant aspect' of the Protocol and which distinguished it from $\mathrm{CA}_{3} \cdot{ }^{38} \mathrm{He}$ therefore concluded that a higher level of intensity of violence is required under AP II conflicts in contrast to the threshold of 'protracted violence' required under $\mathrm{CA}_{3}{ }^{39}$ This view has been confirmed by Boškoski Trial Chamber. ${ }^{40}$ On the other hand, Sandesh Sivakumaran has warned that the notion of AP II 'does [not] require a greater level of violence than that required for' $\mathrm{CA}_{3}{ }^{41} \mathrm{He}$ justified his argument on the basis of a number of ICC pre-Trial Chamber decisions, which 'have utilized the language of AP II, referring to notions of sustained and concerted military operations, even though AP II standards need not be met for the purpose of the ICC' ${ }^{42}$ He therefore concludes that the requisite level of violence for $\mathrm{CA}_{3}$ and AP II is the same. ${ }^{43}$

Cullen (n 11) 96-97, 102; Noelle Quenivet, 'Applicability Test of Additional Protocol II and Common Article 3 for Crimes in Internal Armed Conflict' in Solon Solomon et al (eds), Applying International Humanitarian Law in Judicial and Quasi-Judicial Bodies (тмС Asser Press/Springer 2014) 31, 36-39. is also confirmed by the ICTR in Prosecutor $v$ Rutaganda (n 32) [94]. ibid; Prosecutorv Akayes (n 32) [257].

38 Cullen (n 11) 113 .

39 ibid 128, 142; Andreas Zimmerman, 'Preliminary Remarks on para 2(c)-(f) and para 3' in Otto Triffterer (ed), Commentary on the Rome Statute of the International Criminal Court: Observers' Notes, Article by Article (2nd ed, Hart 2008) 475, 501.

41 Sivakumaran (n 30) 188.

42 ibid.

43 ibid. 
Accordingly, in those cases which fall under the scope of AP II, the Protocol and $\mathrm{CA}_{3}$ will simultaneously apply as the threshold for the application of $\mathrm{CA}_{3}$ is lower than that of the Protocol. On the other hand, $\mathrm{CA}_{3}$ will apply on its own to those cases which fulfil its threshold but fall below the organisation criteria required by AP II ${ }^{44}$ Indeed, the wording of AP II and the remarks of ICRC delegates show that AP II 'develops and supplements' $\mathrm{CA}_{3}$ without interfering with its autonomous application. ${ }^{45}$

\section{Applicability of the Standards of Conflict to the PKK (Kurdish) Conflict in Turkey}

The PKK emerged in 1978 and began an armed struggle against the Turkish government in 1984 to obtain recognition of the Kurds' right to self-determination. The PKK, through its armed struggle, sought to liberate the Kurdish population in Turkey from subjugation to a regime that refused constitutional recognition or protection and, thereby, to establish an independent Kurdish State based on Marxist-Leninist state theory and party model. ${ }^{46}$ As stated previously, Turkey defines the actions of the PKK as 'terrorism' and is reluctant to admit that a state of armed conflict exists within its territory. The Turkish Chief of General Staff referred to clashes between the Turkish security forces and the PKK as 'low-intensity armed conflict', ${ }^{47}$ a conceptualisation of violence that is 'generally used to characterise conflict situations where IHL does not apply'48 Turkey has further justified this approach as the PKK has been proscribed both by the European Union ('EU') and the United States ('USA') as a 'terrorist' organisation: since 1997, the USA has designated the PKK as a 'Foreign Terrorist Organisation'49 Similarly, on 2 May 2002, the Council of Ministers of the EU inserted the name of the PKK in its proscribed list ${ }^{50}$ and the PKK has remained there despite biannual review. ${ }^{51}$ The statements of the reason for proscription of the PKK have 'referred to a list of many incidents ... that were classified as acts of terrorism and have been allegedly

\footnotetext{
44 ibid. This view is affirmed by the ICTR in Prosecutor $v$ Rutaganda (n 32) [94].

45 Cassese (n 26) 424-430; Moir (n 2) 97.

46 Serxwebûn, 'PKK Kurulus Bildirisi' (sayi 447, Adar 2019) <www.serxwebun.org/index. php?sys=naverok\&id=45>.

Sadi Cayci, 'Countering Terrorism and the Law of Armed Conflict: The Turkish Experience' (2002) 8 International Peacekeeping: The Yearbook of International Peace Operations 333.

48 Yildiz \& Breau (n 18) 229.

49 See $n 19$.

50 ibid.

$51 \quad$ Kurdistan Workers' Party (PKK) $v$ Council of the European Union (n 21) [6].
} 
committed by the PKK 52 in the reports of several States, as well as in 'the numbers of the judgments of State Security Court of the Republic of Turkey'.53

However, the wording of paragraphs 1 and 2 of Article 1 of AP II and the ICTR's Akayesu judgment, have left no doubt that the assessment of a NIAC is not dependent on the subjective judgment of the parties involved, but rather has to be made on the basis of objectively verifiable criteria. ${ }^{54}$ Accordingly, provided that the armed conflict between an organised armed group and the State forces objectively fulfils the criteria of $\mathrm{CA}_{3}$ and/or AP II, and the State has ratified and not persistently objected to Geneva Conventions and AP II, the rules of IHL would automatically be applicable to the conflict regardless of the parties' subjective judgment. Indeed, recent judgments of the ECtHR, the ECJ and the Brussels Court of Appeal have indicated that the conflict between the PKK and the Turkish security forces meets the criteria of NIAC.

The ECtHR in Benzer and Others $v$ Turkey ruled that CA3 of the Geneva Convention is applicable to the circumstances that have arisen between the PKK and the Turkish army. ${ }^{55}$ The case concerned the indiscriminate bombing of two Kurdish villages in 1994 during which 34 people, including children, women and elderly people, lost their lives and 13 people were injured. In Benzer, the Court, for the first time in its case law on the Kurdish conflict, cited the principles of IHL regulating the use of force in internal armed conflicts, despite these provisions falling beyond its jurisdiction..$^{56}$ The Court impliedly ruled that Turkey had violated the Geneva Convention by stipulating that:

an indiscriminate aerial bombardment of civilians and their villages ... cannot be reconcilable with any of the grounds regulating the use of force which are set out in Article 2(2) of the [European Convention on Human Rights] or, indeed, with the customary rules of international humanitarian law or any of the international treaties regulating use of force in the armed conflict. ${ }^{57}$

Similarly, the PKK has also been judicially examined as a matter of EU Law, with the ECJ looking more specifically at the status of the PKK, not as a matter of IHL (i.e. whether it is an organised group), but on the cogency of its

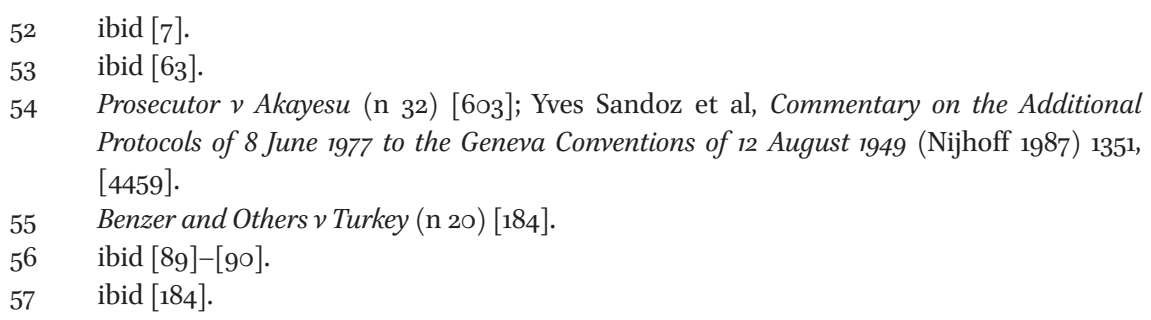


designation as a 'terrorist organisation'. On 15 November 2018, the ECJ in Kurdistan Workers' Party $(P K K) v$ Council of the European Union held that the 'Council was in breach of its duty' for its failure to provide the 'actual and specific reason' why it decided to proscribe the PKK. The Court has justified its finding on the ground that:

the Council cannot, as in this case, do no more than repeat the grounds for a decision of a competent authority while not itself considering whether those grounds are well founded. That applies a fortiori when the decision in question was not taken by a competent authority of a Member State. The statement of reasons for the contested acts specified [for prescribing the $\mathrm{PKK}]$ is such that it is impossible to know whether the Council fulfilled its obligation of verification in that regard and that the Court cannot exercise its power of review as to whether the facts alleged are made out. 58

This demonstrates that the ECJ also underlined that the assessment of the conflict must be assessed on the basis of objectively verifiable criteria and accordingly there is no room to proscribe the PKK on the basis of mere subjective judgment of Turkey. Indeed, the Court explicitly stated that 'the competent European Union authority is under an obligation to examine, carefully and impartially, whether alleged reasons are well founded' 59 Part of the reason why the ECJ was not convinced, was because of the post-1999 ceasefires, meaning the ECJ was essentially looking at/for evidence of violence rather than exploring the terrorism vs armed group distinction. Nonetheless, this also demonstrates the significance of judicial determinations - missing from IHL. On Turkey, the ECtHR in Benzer is as close as we have got to a judicial review of the applicable legal rules. Just as the ECtHR didn't provide a thorough examination of the specific status of the conflict and of the PKK, it is also the case that the ECJ didn't explore the PKK's status under IHL but rather found lack of diligence and administrative compliance with the 'terrorist' designation process.

Finally, on 8 March 2019, the Court of Appeal of Brussels discontinued the prosecution of 39 individuals and two media companies affiliated to the PKK on the grounds that the PKK is not a 'terrorist' organisation and qualified it as an armed force party to a NIAC with Turkey. ${ }^{60}$ The main issue in this case revolved around the IHL exclusion clause contained in Article 141 bis of the Belgian Criminal Code, which aims to keep separate the application of IHL

\footnotetext{
$5^{8} \quad$ Kurdistan Workers' Party (PKK) $v$ Council of the European Union (n 21) [109].

59 ibid [111].

6o Brussels Court of Appeal (n 22) 22.
} 
and the criminal law sanctioning terrorist offences. ${ }^{61}$ This clause directly implemented recital 11 of the 2002 EU Framework Decision on combating terrorism. The relevant part provides that:

Actions by armed forces during periods of armed conflict, which are governed by international humanitarian law within the meaning of these terms under the law ... are not governed by this Framework Decision. ${ }^{62}$

The Court held that the IHL exclusion clause is applicable to the PKK case as the PKK is not a terrorist group in the sense of Belgian law but rather 'is party to an armed conflict within the sense of IHL against the Turkish state in Turkey'.63 The Court justified its decision on the grounds that the PK K fulfilled the requisite criterion, namely organisation and intensity, of NIAC within the context of $\mathrm{CA}_{3}: 64$ the Court found that the PKK possess organised armed forces by briefly examining the PKK command structure, its numbers of members and the weapons which the PKK has possessed. Then by briefly referring to statistics in relation to the deaths and the destructions of properties in the Kurdish area, the Court concluded that the clashes between the Turkish forces and the PKK militants fulfils the intensity requirement under $\mathrm{CA}_{3} \cdot{ }^{65}$

Despite the importance of these judgments regarding the status of the NIAC in Turkey, judges have been reluctant to provide reasons, apart from brief analysis by the Court of Appeal Brussels, for this conclusion. The following examination seeks to provide greater clarity by analysing Turkey's international obligation under IHL and the capacity of the PKK to meet the relevant criteria regarding NIAC s.

\section{1 \\ Are Common Article 3 and Additional Protocol II Applicable to Turkey?}

As a matter of treaty law, Turkey is bound by the provisions of $\mathrm{CA}_{3}$, regardless of its position on the status of the conflict and of the PKK. It signed and ratified the four 1949 Geneva Conventions which contain $\mathrm{CA}_{3}$ in $1954 \cdot{ }^{66}$ In addition to its treaty status, $\mathrm{CA}_{3}$ is also recognised as holding the status of CIL, meaning it

\footnotetext{
61 ibid 12.

62 ibid 13.

63 ibid 22.

64 ibid $15^{-16 .}$

65 ibid 14-16.

66 ICRC, 'Treaties, States Parties and Commentaries' <ihl-databases.icrc.org/applic/ihl/ihl. nsf/vwTreatiesHistoricalByCountry.xsp >.
} 
applies to all States regardless of treaty recognition, as confirmed by the ICJ in its Nicaragua judgment:

Article $3 \ldots$ defines certain rules to be applied in the armed conflicts of a non-international character. There is no doubt that, in the event of international armed conflicts, these rules also constitute a minimum yardstick, in addition to the more elaborate rules which are also to apply to international conflicts; and they are rules which, in the Court's opinion, reflect what the Court in 1949 called 'elementary considerations of humanity' 67

The call to humanity emphasises the core, fundamental and non-derogable status of $\mathrm{CA}_{3}$. The same view of the customary status of $\mathrm{CA}_{3}$ has been confirmed in a succession of judgments of various international criminal tribunals. ${ }^{68}$ Therefore, it can be concluded that Turkey is clearly bound by $\mathrm{CA}_{3}$ through treaty law and customary IHL.

However, the situation regarding AP II is more complicated, as Turkey has neither signed nor ratified ${ }^{69}$ and, in fact, has persistently objected to the application of AP II to the conflict with the PKK, hence its treatment of the problem as a matter of counter-terrorism. As a matter of treaty law, as governed by the Vienna Convention on the Law of Treaties, ${ }^{70}$ Turkey is therefore not bound by AP II. Nevertheless, if AP II has acquired the status of customary IHL, then Turkey would have to respect the obligations as part of customary IHL regardless of treaty recognition. Accordingly, the question arises whether AP II has obtained the status of customary IHL.

It is commonly accepted that many provisions contained in AP II have acquired the status of CIL. For example, in 1987 the Deputy Legal Adviser of the US State Department expressed that the 'basic core' of AP II, 'reflected in Common Article 3 of the 1949 Geneva Conventions and therefore is, and should be, a part of generally accepted customary law. ${ }^{\prime 1}$ This expansive approach was

$67 \quad$ Nicaragua v United States (n 8) [218]; ICRC, 'Customary International Humanitarian Law' $<$ ihl-databases.icrc.org/customary-ihl/eng/docs/vı_rul_in>.

68 See Legality of the Threat or Use of Nuclear Weapons (Advisory Opinion) [1996] ICJ Rep 226, 257-258, 279, 282; Barcelona Traction Light and Power Company Limited (Judgment) [1970] ICJ Rep 3, [33]-[35]; Prosecutorv Akayesu (n 32) [6o8]; Tadić (n 32) [617].

$69 \quad$ ICRC (n 66).

70 See Vienna Convention on the Law of Treaties (adopted 23 May 1969, entered into force 27 January 1980) 1155 UNTS 331 (VCLT) art 62.

71 Tadić (n 3) [117]. See also Theodor Meron, Human Rights and Humanitarian Norms as Customary Law (oup 1991) 73; Sandoz et al (n 54) 1341. 
authoritatively affirmed in the 1995 decision of the ICTY in Prosecutor $v$ Tadić. The Appeal Chamber stated:

Many provisions of this Protocol can now be regarded as declaratory of existing rules or as having crystallised emerging rules of customary law or else as having been strongly instrumental in their evolution as general principles. ${ }^{72}$

The Chamber's opinion touches on a major problem. While there is a notable imprecision in its opinion as to how and also which specific provisions of AP II have acquired a customary nature, the Chamber was unsure as to whether the Protocol was declaratory of existing rules, crystallised emerging rules, or has evolved as a set of general principles. ${ }^{73}$ The Trial Chamber went further in Martić, stating that 'violations of the Additional Protocol II constitute violations of the laws or customs of war'. ${ }^{74}$

However, there is not authoritative evidence confirming the customary IHL status of AP II as a whole due to neither the Customary International Humanitarian Law Study nor judgments of international criminal tribunals claiming that AP II as a whole has acquired the status of CIL. Accordingly, Turkey is not bound by the entirety of AP II, either through treaty law or CIL.

\subsection{Does the PKK Fulfil the Requirements of NIAC under Common Article 3?}

In order to establish whether the hostilities between the PKK and the Turkish security forces qualify as a NIAC under CA3 and customary I HL, we must assess whether the PKK fulfils the three main criteria laid down in I HL treaty law, and developed by indicative factors in international jurisprudence for assessing existence of a NIAC in the context of CA3. The following discussion demonstrates that the PKK has met these three criteria, namely: being an organised armed group, having the ability to engage in 'protracted violence' and comply with law of armed conflict. It also reveals that the PKK was able to exercise

Tadić (n 3) [117]. According to the 2005 Customary International Humanitarian Law Study the following provisions of AP II have obtained the status of customary IHL: art 2(1), art 4 as a whole, art 5(1)(b), (c), (d), (e), 5(2)(a), (c), (d), (e), art 6 as a whole, art 7 as a whole, art 8, art 9 as a whole, art $10(3),(4)$, art 11 as a whole, art 12, art 13 as a whole, arts 14, 15, 16, art 17(1), art 18 as a whole. See J-M Henckarets \& L Doswald-Beck, Customary International Humanitarian Law (ICRC 2005) vol I, 300-6102.

73 Prosecutorv Akayesu (n 32) [6o9].

74 Prosecutor $v$ Martic (Rule 61) [1995] ICTY-95-13-R61 (8 March 1996) [8]. 
control over territory, which although not determinative, is nonetheless one possible indicator of the existence of a NIAC under CA3.

\subsubsection{The Organised Armed Group Requirement}

It is universally accepted that a non-State armed group engaged in hostilities with a State's forces must have a certain level of organisation to qualify as a party to a NIAC within the context of CA3. ${ }^{75}$ The ICTY Trial Chambers underlined that organised armed groups 'do not necessarily need to be as organised as the armed forces of a State. ${ }^{76}$ Therefore, the requisite degree of organisation 'must not be exaggerated'. As stated by various international criminal tribunals, 'some degree of organisation'77 or 'a greater or lesser degree'78 of organisation by the parties will suffice. The IHL treaty law and international jurisprudence spell out three main reasons for rationality of the requisite degree of organisation. ${ }^{79}$ The first reason is based on interdependency between the requirement of organisation of a non-State armed group and its ability to fulfil the 'protracted violence' requirement. The ICTY, in its Haradinaj et al judgment, underlined that all parties to an armed conflict must be 'sufficiently organised to confront each other with military means' ${ }^{80}$ Second, the functioning of organisation of a non-State armed group demonstrates the collective character of the violence, which is therefore carried out by the collective entity rather than by random individuals. ${ }^{81}$ Third, it has been submitted within international jurisprudence and by scholars that a non-State armed group needs to be sufficiently organised in order to have the ability to respect basic humanitarian requirements of the law of armed conflict. ${ }^{82}$

75 Lindsay Moir, 'The Concept of Non-International Armed Conflict' in A Clapham, P Gaeta and M Sassoli (eds), The 1949 Geneva Conventions: A Commentary (oup 2015) 391 [35]. See also International Law Association ('ILA'), Final Report on the Meaning of Armed Conflict in International Law (ILA 2010) 28-29.

$76 \quad$ Prosecutorv Boskoski \& Tarculovski (n 36) [197].

77 Prosecutor $v$ Limaj [2005] ICTY IT-о3-66-T (30 November 2005) [89].

78 Prosecutor $v$ Musema (Judgment and Sentence) [2000] ICTR-96-13-T (27 January 2000) [248].

79 Sivakumaran (n 30) 177; Tilman Rodenhauser, Organizing Rebellion: Non-State Armed Groups under International Humanitarian Law, Human Rights Law and International Criminal Law (Oup 2018) 72.

8o Prosecutorv Haradinaj, Balaj, Brahimaj (Trial Judgment) [2008] Case No. IT-04-84-T, T.Ch.I (April 2008) [6o].

81 Prosecutorv Tadić (Appeal Judgment) [1999] IT-94-1-A (15 July 1999) [120]; Rodenhauser (n 79) 73 .

$82 \quad$ ILA (n 75) 29; Sivakumaran (n 30) 177; Rodenhauser (n 79) 87-9. 
International criminal tribunals and the ICC Chambers have underlined that non-State armed groups must possess command structures which 'exercise an effective control over subordinates' 83 in order to function as organised and satisfactorily carry out the above- mentioned three essential criteria. The notion of command structure, as stated by the Tadić Appeals Chambers, distinguishes the organised armed group from randomly connected individuals in the sense that its members 'conform to the standards prevailing in the group and are subject to the authority of the head of the group' ${ }^{84}$ It is important to highlight that the notion of command structure neither requires a hierarchical military structure with a leader at the top nor a strict chain of command. ${ }^{85}$ The crucial point for satisfying this requirement, as stated by the Report of the Secretary-General of the United Nations, is to demonstrate that there are individuals who are 'capable of ensuring generally the execution of ... orders, including, as far as possible, respect of the laws and customs of war.' 86

Various international tribunals have suggested a number of indicative factors for assessing the requisite level of organisation of an armed group in line with $\mathrm{CA}_{3}$. These non-cumulative 'organisational criteria' were consolidated by the Boškoski Trial Chamber under the following five groups:

a. The existence of a command structure;

i. Indicators: the existence of headquarters; uniforms; a general staff or high command; internal regulations; the issuing of political statements or communiques; spokespersons; identifiable ranks and positions.

b. The existence of military capacity;

i. Indicators: the ability to define a unified military strategy; to use military tactics; to carry out large scale or coordinated military operations; the control of certain territory.

c. The existence of logistical capacity;

i. Indicators: the existence of supply chains (ability to procure, transport and distribute arms); the ability to recruit new members and train them; ability for troop movement.

d. The existence of an internal disciplinary system and the ability to implement IHL;

i. Indicators: the existence of disciplinary rules or mechanisms within the group.

\footnotetext{
83 Rodenhauser (n 79) 86; for full discussion see 74-8. Sivakumaran (n 30) 74-76.

$84 \quad$ Tadić (Appeal Judgment) (n 81) [120].

85 Prosecutorv Delalic (n 31) [30]; Sivakumaran (n 30) 175.

86 UNGA, 'Respect for Human Rights in Armed Conflicts' (18 September 1970) UN Doc $\mathrm{A} / 8 \mathrm{o5} 2,[176]$.
} 
e. The ability of the group to speak with one voice;

i. Indicators: the capacity to act on behalf of its members in political negotiations and conclude cease fire agreements. ${ }^{87}$

A sufficient body of evidence shows that the PKK fulfils each of these broad requirements. The $\mathrm{PKK}$ is a strict hierarchical organisation according to the principle of democratic centralism. It consists of a Central Executive Committee led by Abdullah Öcalan. The task of this body is to supervise the overall activity of the movement and to represent and speak on behalf of the organisation. This body is presided over by a Central Committee which is the main governing body of the PKK. This committee is elected by the members of the PKK during its Annual Congress. The Central Committee consists of many subcommittees such as youth, women, students, disciplinary, political, judicial and military. ${ }^{88}$

The political wing of the PKK, the National Liberation of Kurdistan ('ERNK/ KCDK'), was established in 1985 and has carried out propaganda activities, recruited new members, raised funds, provided intelligence and counter-intelligence for operational security, conducted political training for militants and established contact with external bodies such as the State, other insurgents and armed groups. ${ }^{89}$ The PKK carries on the recruitment of people, especially of Kurdish origin, in a systematic and organised way in Turkey, Iraq, Syria, Iran and even in Western Europe. ${ }^{90}$ The PKK's systematic recruitment policy and its funding policy provide clear evidence of the PKK being a well-organised armed group. The number of the PKK's members sharply increased from 200 armed members in 1984 to 15,000 to 20 , ooo guerrillas by the beginning of $1993 \cdot{ }^{91}$ The fact that the PKK lost 30,000 members in the fight with the Turkish security forces in the $1984-2017$ time period, ${ }^{92}$ and has more than 15 ,000 guerrillas consisting of men and women at the present, indicates the organised and

$87 \quad$ Prosecutor v Boskoski \& Tarculovski (n 36) [194]-[203]. See also Prosecutor v Slobodan Milosevic [2004] ICTY-02-54 (16 June 2004) [23]; Prosecutor v Limaj (n 77) [9o].

88 Serxwebûn, 'PKK (Partiya Karkeren Kurdistan) Program ve Tuzuk' (sayi 71, Nisan 1995) 84-99; A Marcus, Blood and Belief: the PKK and the Kurdish fight for independence (New York University Press 2007) 47; Yildiz \& Breau (n 18) 15.

89 Berxwedan, 'Kurdistan Ulusal Kurtulus Cephesi'nin Ilani Ile Ilgili Olarak; Kurdistan Halkinin Ulusal Onderi ve PK K Genel Sekreteri Abduallah Öcalan Bir Konusma Yapti' (sayi 9, Nisan 1985) 10; A Öcalan 3. Kongre Konusmalari (Wesanen Sexwebun 1993) 151; Yildiz \& Breau (n 18) 15 .

$90 \quad$ Europol, TESAT-European Union Terrorism Situation and Trend Report (2018) 12, 18, 46.

91 U Ozdag, The PKK and the low intensity Conflict in Turkey (Frank Cass 2003) 39; J Jongerden, The Settlement Issue in Turkey and the Kurds (Brill 2007) 61-63.

92 'Mukayese: sayilarla 1984'ten bu yana РКк ile catismalardaki olumler' (140Journos, 24 March 2017) <140journos.com/sayilarla-1984ten-bu-yana-pkk-ile-catismalardaki-olumler5 ce123d214be>. 
systematic aspect of the PKK recruitment policy and the effectiveness of its military training for combat with the Turkish security forces. ${ }^{93}$ Similarly, the PKK has a systematised financing policy. The armed struggle of the PKK has been funded through a 'revolutionary tax. ${ }^{94}$ According to a NATO Terrorist Threat Intelligence Unit report the PKK raises a 'total of $\$ 50$ to $\$ 100$ million per year'. ${ }^{95}$

A quick glance at the structure and operation of the military wing of the PKK, the Kurdistan People's Liberation Army ('ARGK/HPG'), further proves how systematically the armed defence of the PKK is organised. The ARGK/HPG consists of regular mobile forces, guerrilla units, militia and self-defence units and armed city partisans. The ARGK/HPG is responsible for providing military training to new militants, and takes direct military action against Turkish military forces. ${ }^{96}$ The capability of the PKK to coordinate a unified military strategy through a chain of command and the operational effectiveness of this strategy also shows the level of organisation within the РКк. The command structure employed by the PKK plays a crucial role in the overall functioning of the organisation. The ARGK/HPG holds its conference every two years. It comprises the members of the Council and elected delegates from local units. The delegates of the Conference elect the Council of the ARGK/HPG (composed of 41 members) and implement strategic military plans. The Council, in turn, elects the 13-member Command Council. The Command Council elects, with a $2 / 3$ majority, the Commander-in-Chief of the ARGK/HPG. Daily operational command is exercised by a General Staff under the leadership of the Commander-in-Chief. The Command Council appoints zone commanders and gives direction to various units within the PKK. The zone commanders give orders to subordinate groups and soldiers. ${ }^{97}$ The latter are obliged to obey such orders as otherwise they would be subjected to disciplinary procedures. ${ }^{98}$ This indicates how the PKK has a developed and documented system of military discipline within an organised leadership structure.

Akit, 'Kac tane PKK'li terrorist var?' (24 August 2015); N A Ozcan, 'Suriye'de PKK'li Varligi' (Milliyet, 12 March 2019); 'Raporlara ve beyanatlara yansiyan sayilarla PKK'ya katilim oranlari' (140Journos, 21 April 2017) <140journos.com/ raporlar-ve-beyanatlara-yansiyan-sayilarla-pkkya-katilim-oranlari-f79d736775e5>.

Europol (n 9o) 12, 18, 46; P Wittrock, 'How the PKк Operates in Europe' (Spiegel Online, 11 July 2008); 'French court sentenced 9 Kurds in PKK extortion case' (HurriyetDailyNews, 26 March 2015). Artesa Rizgariya Gele Kurdistan ('ARGK'), ARGK Genel Yonetmenligi (Kurdistan People's Liberation Army (ARGK)'s Code of Conduct) (Weşanên Serxwebûn, Roj Matbaasi 1995) 19-20, 64-69, 96-117.

$97 \quad$ ibid $13-17,21-25,31-51$.

98 ibid $166-179$. 
The ARGK/HPG Council also organises the purchase and supplies of weapons and ammunition and distributes them to the units. The ability of the ARG K/ HPG to change its military tactics also reveals that the PKK has a unified military strategy which is implemented through the hierarchy of a command structure. ${ }^{99}$ In the second half of the 198 os, the PKK carried out extensive attacks on the Turkish security forces, which forced the army to withdraw from rural areas of the Kurdish region for the sake of defending larger settlements and villages. By the end of 1991, the PKK transformed its guerrilla warfare tactics into a conventional military strategy with the intention to extend its control from rural areas to towns by controlling towns for weeks through popular uprisings. ${ }^{100}$ The PKK re-implemented its urban combat tactics after the collapse of the peace talks with the Turkish government in 2012 and 2015, in the whole of the Kurdish region as part of its 'revolutionary people war'101 and where clashes have taken place for months and more than a year respectively. ${ }^{102}$ This proves the capability of the PKK to formulate and declare a change of the military tactics as well as conditions for refraining from military actions in accordance with any peace process.

Further evidence that the PKK fulfils the threshold requirement for organisation is that it has long-established bases, ${ }^{103}$ including headquarters in Qandil Mountains in Northern Iraq; ${ }^{104}$ its members wear uniforms in the mountains; and the organisation implements strict internal disciplinary procedures. ${ }^{105}$ Finally, the capability of the PKK to go through with a series of ideological and structural transformations can be observed at various points throughout the conflict: the PKK replaced its aim of establishing an independent Kurdistan within the territory of Turkey with the concept of democratic autonomy within

\footnotetext{
$99 \quad$ ibid $96-136$.

$100 \quad$ Jongerden (n 91) 61-63.

101 Serxwebûn,'Dorduncu stratejik mucadele donemi-4 Devrimci Halk Savasi'nin hedefleri' (sayi 38, 447 Adar 2009); B Hozat, 'Yeni Surec:Devrimci Halk Savasidir' (Ozgur Gundem, 14 July 2015).

102 Office of the United Nations High Commissioner for Human Rights ('OHCHR'), 'Report on the Human Rights Situation in South-East Turkey, July 2015 to December 2016' (February 2017) [2]; International Crisis Group, 'Turkey: The PKK and the Kurdish Settlement' (Europe Report No 219) 2.

103 International Crisis Group (n 102) 7.

104 'Turkish Military Launches Qandil Operation to Destroy the PKK Headquarters' (Daily Sabah, 12 June 2018) <www.dailysabah.com/war-on-terror/2018/o6/12/ turkish-military-launches-qandil-operation-to-destroy-pkk-headquarters >.

105 Serxwebûn (n 88) 19-22; Marcus (n 88) 108; E Dogu, 'P KK: Partiya Karkeran Kurdistan' in M Heiberg et al (eds), Terror, Insurgency and the State (University of Pennsylvania 20o8) 33 .
} 
Turkey that would accommodate the Kurds' cultural, linguistic and political demands in 2000; ${ }^{106}$ the issuing of political statements; the declaration of several unilateral ceasefires ${ }^{107}$ and recent peace talks (2006-2011 and 2012-2015) with Turkey mediated by the United Kingdom ${ }^{108}$ demonstrate that the PKK has managed to speak with one voice. Indeed, strict obedience of PKK members to retreat from Turkey's territory after instruction of their abducted leader Öcalan in May $2013^{109}$ demonstrated PKK commitment to the peace process and a high level of organisation and coordination. In considering the ongoing hostility between the PKK and the Turkish security forces since 1984, it can be concluded that the PKK meets the requirement as an organised armed group as it has achieved a level of organisational stability and effectiveness.

\subsubsection{The Requirement of Intensity}

Organised armed groups must '...have the ability to plan and carry out military operations for a prolonged period of time'110 against the State's military forces in order to satisfy the required threshold of 'protracted violence' under CA3. The 'protracted violence' necessitates criterion that violence be of a certain level of intensity in order to transform a conflict into a NIAC ${ }^{111}$ and distinguish it 'from cases of civil unrest ... or terrorist activities which are not subject to international humanitarian law'.112 Different opinions have been expressed on how to identify the requisite level of intensity. The main question is whether the gravity of violence or its duration should be the principal determinative factor in assessing the intensity threshold under $\mathrm{CA}_{3}$. Yoram Dinstein rightly

106 A Öcalan, Savunma: Kurt Sorununda Demokratik Cozum Bildirgesi (Mem Yayinlari 1999) 17-18, 32, 111-112; A H Akkaya and J Jongerden, 'The PKK in the 200os: Continuity through Breaks?' in Marlies Casier and Joost Jongerden (eds), Nationalisms and Politics in Turkey, Political Islam, Kemalism and the Kurdish Issue (Routledge 2010) 143-62, 147-55. PKK has declared 7 ceasefires during 19 years: 'Öcalan bugune kadar 7 kez ateskes ilan etti' (Milliyet, 22 March 2013) <www.milligazete.com.tr/haber/1062098/Öcalan bugune-kadar-7-kez-ateskes-ve-cekilme-ilan-etti>.

International Crisis Group (n 102) 3; H Soylemez, 'Oslo'daki O Kadın Konustu: Iradenin Yurutucu Gucu Kandil'dir' (Aksiyon, 14 January 2013); M Yegen, 'The Kurdish Peace Process in Turkey: Genesis, Evolution and Prospects' (Working Paper 11, Sehir University 2015) $5^{-14}$

'Öcalan'ın Tarihi Mesajı: Silahı Bırakın, Sınır Dışına Çıkın' (Radikal, 21 March 2013); 'PKK Begins to Withdraw from Turkey' (Guardian, 8 May 2013).

Prosecutor v Lubanga Dyilo (Decision on the Confirmation of Charges) [2007] ICC-01/04ol/o6, Pre-Trial Chamber I (29 January 2007) [234]; Prosecutorv Al-Bashir (Decision on the Prosecution's Application for a Warrant of Arrest) [2009] ICC-02/O5-01/o9 (4 March 2009) [6o].

111 Tadić (n 3) [70]; Prosecutor v Boskoski (n 36) [175]; Prosecutorv Haradinaj (n 80) [39].

112 Prosecutorv Delalic (n 31) [184]. 
stated that both components are complementary, and emphasised that ' $\mathrm{v}$ ] iolence that is protracted but not intense, or intense but not protracted does not amount to a NIAC'.113 This view has been endorsed by the ICTY, which has incorporated both components amongst its several non-cumulative 'intensity of hostilities criterion' in assessing the intensity of armed violence in the context of $\mathrm{CA}_{3}$. The list of these indicative factors was spell out by the Boškoski \& Tarčulovski Trial Chamber after reviewing cases before the International Criminal Tribunal as follows:

a. The seriousness of armed clashes over territory and a period of time;

b. The use of armed force, and the quantity and mobilisation of troops by the government;

c. The type of actions, such as besieged towns, blockages of supply routes and closure of roads;

d. The type of weapons, ammunitions and other military equipment used by the parties, such as tanks and other heavy vehicles; and

e. Effects on the civilian population, such as the displacement of local population and extent of destruction. ${ }^{114}$

Have the PKK's military activities reached the threshold of 'protracted violence' in the context of $\mathrm{CA}_{3}$ ? The diary of the PKK commander, Mahsum Korkmaz, goes into great detail on how PKK militants planned their first military operation and took control of two towns in the Kurdish region in south-east Turkey in $1984 .{ }^{115}$ The recent book released by the ex-co-chair of the Executive Central Committee of the PKK, Murat Karayilan, also provides a detailed account of how the PKK guerrillas planned, coordinated and executed armed attacks against Turkish security forces and their bases. ${ }^{116}$ Furthermore, the PKK has possessed and used heavy weapons, including AKM assault rifles, M-16 and G-3 rifles, RPG-7 shoulder-launched rocket-propelled grenades, $\mathrm{C}_{3}$ and $\mathrm{C}_{4}$ explosives. ${ }^{117}$ Since 1984, the PKK enjoyed a significant level of overall military success, tying up the Turkish forces with guerrilla tactics.

The use of troops by the Turkish government and the declaration of the state of emergency in the Kurdish region are further valuable evidence to demonstrate the occurrence of 'protracted violence' between the Turkish security forces and the Ркк. The Turkish Governments maintained a state of

\footnotetext{
113 Yoram Dinstein, Non-international Armed Conflicts in International Law (CUP 2014) 35.

114 Prosecutorv Boskoski \& Tarculovski (n 36) [177]-[178].

115 F Cetin and I Kayhan, Komutan Agit'in Gunlugunden - Mahsum Korkmaz (Mezopotamya 1997).

116 M Karayilan, Bir savasin Anatomisi: Kurdistan'da Askeri Cizgi (Mezopotamya 2013).

117 'PKK'da hangi silahta kac tane var?' (Mynet, 9 November 2017) <www.mynet.com/ pkkda-hangi-silahtan-kac-tane-var-11010068659o>.
} 
emergency between 1987-2002 in 13 out of 17 cities of south-eastern Turkey, which covered 488-61o hectares of Turkey, and had recourse to its regular armed forces in its fight to wrestle back control of the region from the PKK. ${ }^{118}$ Turkish security forces conducted large-scale operations against the PKK during this time period. ${ }^{119}$ For example, in 1993 the State carried out operations with almost half of its land forces of 185 ,000 soldiers, special police units, special anti-terror unit and, village guards. These forces amounted to more than 300,000 members ${ }^{120}$ against 15,000-20,000 guerrillas. Though the Turkish army has conducted air offensives, air bombardments and deployed war planes against the $\mathrm{PKK}$, the State armed forces rapidly lost control of the Kurdish region between 1990 and $1995 .{ }^{121}$ Since then, the Turkish army has systematically employed even more intensive pattern of military actions against the PKK. For example, International Crisis Group noted that in August 2012 alone, Turkish security forces made at least ' 400 incidents of shelling, air bombardment, clashes or other armed actions' against the PKK. ${ }^{122}$

Although the Turkish security forces were far more numerous and better trained and equipped, they have been unable to defeat the PKK. The PKK, apart from the ceasefire periods, has launched countless ongoing attacks against many 'legitimate targets' which includes 'members of the Turkish security forces; members of Turkish contra-guerrilla forces; members of the Turkish Intelligent Service and village guards'. ${ }^{123}$ The HPG's armed actions take several forms: kidnapping, sabotage, and destruction of infrastructure, roadblocks, shooting incidents, actions involving the killing of individuals, and bombings. ${ }^{124}$ The intensity of attacks reached a peak after the PKK declared to establish the 'Botan-Behdinan War Government' within the territory of south-eastern Turkey and the north of Iraq at its fourth Congress on $26-31$ December 1990. ${ }^{125}$ The PKK has established strict territorial control in the rural

118

119

120

121

122

123

124

125

Resmi Gazette, 'Olagan Ustu Hal Kanunu' (Kanun 285, no 19517, 14 July 1987).

'Sinir otesi operasyonlar 1983'te basladi' (CNNTurk, 22 February 2008) < www.cnnturk. com/2008/turkiye/o2/22/sinir.otesi.operasyonlar.1983te.basladi/430959.o/index.html>.

Human Rights Watch ('HRW'), Weapons Transfers (1995) 24. U Ozdag (n 91) 39; J Jongerden (n 91) 61-63.

International Crisis Group (n 102) 2.

Kurdistan Workers' Party ('PKK') Statement to the United Nations (24 January 1995). See also for actions of the PKK against these 'legitimate targets', O F Cantenar and F Tumlu, 'PKK Teror Orgutunu Eylemlerinin Guvenlik Gucleri Zayiati Acisindan Analizi' (2016) 26(1) Kara Harp Okulu Bilim Dergisi 1, 4-17.

Cantenar \& Tumlu (n 123) 4-17.

Serxwebun, '15 Agustos Ruhuyla Devrimci Halk Savasina' (sayi 356, Agustos 2011) 8; T Eren, 'Şerik: PKK, Kürdistan halkını koruma mücadelesini sürdürecek' (ANF, 29 November 2019). 
areas of the Botan-Behdinan region which covered more than 15,000 hectares between 1990 and $1995 .{ }^{126}$ During that time, the PKK systematically attacked almost all the Turkish military bases along the border of Iraq in order to demolish the border between both Kurdish regions. Amongst hundreds of attacks, ${ }^{127}$ some of the most bloodiest were raids of the Turkish military bases by the PK K militants on 25 October 1991, 29 September 1992, 2 July 1993, 13 August 1994 and 15 June 1995, which caused the killing of $33,28,16,15$, and 15 soldiers respectively. ${ }^{128}$ In parallel, the PKK also launched military operations to take control of some cities and towns in the Botan region, even before Öcalan declared a 'total war' against the Turkish State on 8 June $1993 .{ }^{129}$ According to state statistics, the PKK's militants, which consisted of more than 500 and 200 people, attacked both city of Sirnak and town of Cukurca respectively between 18-25 August 1992 and held these places for a couple of days. ${ }^{130}$ Similarly on 27 June 1993 and 15 August 1993, the PKK militants started heavy military operations in towns of Cukurca and Yuksekova respectively. ${ }^{131}$ It is reported that the PKK militants used more than 500 rockets against the State military forces during their attack in Yuksekova. ${ }^{132}$ The PKK attacks against the Turkish military forces spread across the entire south-east of Turkey during that time. ${ }^{133}$ These intense guerrilla actions led Turkey's Chief of the General Staff at the time, Dogan Gures, to admit the existence of an 'unnamed war' between the PKK and the Turkish security forces. ${ }^{134}$

The PKK has managed to carry out more intense military operations against the Turkish security forces after the collapse of the longest peace talks in 2004, despite its forces having withdrawn from Turkish territory from 1 September 1999 to May 2004. ${ }^{135}$ For example, on 21 October 2007, the PKK militants

\footnotetext{
126 N Yazici, 'Hakkâri Türkiye'nin Bir Vilayeti Değil mi?' (Turk Yurdu 2014).

127 For detail of these attacks, see N Yazici, PKK'nin Hakkari Projesi: 1984-2013 (Alibi 2016) 126205; O Pamukoglu, Unutulanlar Disinda Yeni Bir Sey Yok (Inkilap 2004) 76-84.

128 ibid. See also Milliyet, 'Sinirda Buyuk Harekat' (26 October 1991); Milliyet, '23 Asker, 5 Korucu Sehit, 54 PKK'li Olu' (30 September 1992); Hurriyet, 'En çok şehit verdiğimiz dördüncü saldırı' (20 October 2011); Milliyet, 'P K K'ya Agir Darbe' (14 August 1994).

129 Milliyet, 'PKK'da Saldiri Hazirligi' (18 June 1993); N Yazici (n 126) 162.

130 Turkiye, 'Sirnak Savas Alani Gibi' (20 August 1992); Tercuman, 'Kansizlarin Cureti' (20 August 1992); Milliyet, 'Sirnak'a Gece Baskini: 4 Sehit' (2o August 1992).

131 Pamukoglu (n 127) 127; Yazici (n 127) 163, 170.

132 Milliyet, '400 PKK'li Cemberde' (17 August 1993).

133 Marcus (n 87) 96; J Jongerden \& A Akkaya, PKK Üzerine Yazılar (Vate 2012) 239.

134 Cumhuriyet, 'Gures: Adi Konulmamis Savas' (28 May 1992).

135 Lekolin, 'Kurt Ozgurluk Hareketi Ateskesler Kronolojisi' (23 August 2010) <www.lekolin. org/kurt-ozgurluk-hareketi-ateskesler-kronolojisi/>; A Takan,'Ркк'nin Kongre Tarihi' (Yenicag, 26 March 2015).
} 
attacked Turkish soldiers in a military base in Oremar in Hakkari province and killed 35 soldiers and abducted 8 of them. ${ }^{136}$ Similarly, on 19 October 2011 and 7 September 2015, the PKK militants attacked Daglica military base and killed 24 soldiers and wounded 18 soldiers, and killed 16 soldiers and wounded 6 soldiers respectively. ${ }^{137}$ Likewise, the group of PKK's militant attacked the Turkish military convoy in Bingol and killed 10 soldiers and wounded 71 soldiers on 18 September 2012. ${ }^{138}$ According to official Turkish figures, 7,230 Turkish troops were killed and 21,238 injured in their fights with the PKK between $1984-2015 \cdot{ }^{139}$

The PKK ceased its military attacks against the security forces between March 2013 and June 2015 while the Turkish State held the most serious peace talks. ${ }^{140}$ However, after the collapse of the peace talks in June 2015 and in response to attacks on the PKK and mass arrest of Kurds, including academics, MP s and mayors, the PKK has declared a 'Revolutionary People's War'141 against Turkey. The PKK re-implemented its 1993 strategy to gain control of Kurdish urban areas in a more systematic, large-scale and widespread level in the Kurdish region in July 2015. As a part of this strategy, the PKK's urban youth militia Civil Defence Units ('YPs') held geographical control of 10 Kurdish cities, 39 towns and 63 districts, being an area 270 kilometres from north to south and 35 o kilometres from east to west. ${ }^{142}$ The PKK youth militia declared democratic self-governance in this area between August 2015 and April 2016 and engaged in military confrontations with the Turkish security forces. ${ }^{143}$ In response, the Turkish State imposed curfews in the Kurdish region from

136 HPG Anakaragah Komutanligi, 'Oremardaki Son Catismalarin Sonucu: 35 Asker oldurulken, 8 asker de esir alindi' (22 October 2007) <hezenparastin.info/tr/news/ news_535_1.html>.

Sabah, 'Hakkari'de Hain Saldiri: 24 Sehit' (19 October 2011) <www.sabah.com.tr/ gundem/2011/10/19/hakkaride-hain-saldiri-21-sehit>; ввC, 'TSк: Dağlıca'da 16 asker şehit' (7 September 2015) <www.bbc.com/turkce/haberler/2015/o9/1509o6_daglica_saldiri>. Bingol Online, 'Askeri konvoya roketli saldırı: 10 şehit 71 yaralı' (18 September 2012) <www. bingolonline.com/haber/askeri-konvoya-roketli-saldiri-10-sehit-71-yarali-4172o.html>.

139 TRTHaber, 'PKK 1984'ten beri 7bin sivili katletti' (27 August 2015).

140 Y Ogur, 'İşte Çözüm Süreci'nin kronolojisi' (11 August 2015) <odatv4.com/iste-cozumsurecinin-kronolojisi-110815120o.html>.

141 D Kendal, 'Karayllan: Bizi savaşla yok etmek istiyorlarsa buyursunlar!' (ANF, 6 August 2015).

142 онсHR (n 102) [42]; Council of Europe, Commissioner for Human Rights: Memorandum on the Human Rights Implications of Anti-Terrorism Operations in South-Eastern Turkey (2 December 2016) [16]; Turkiye Insan Haklari Vakfi ('TIHV'), '16 Agustos 2015-1 Haziran 2016 Tarihleri Arasinda Ilan Edilen Sokaga Cikma Yasaklari' (1 Haziran 2017).

143 онснR (n 102) [2]; 'Ozyonetim ilan edilen merkez sayisi 16'ya yuksledi' (T24, 20 August 2015) <t24.com.tr/haber/oz-yonetim-ilan-edilen-merkez-sayisi-16ya-yukseldi,306949>. 
August 2015 until April 2016. ${ }^{144}$ During that time, the most intense, sustained and concerted clashes between the PKK and Turkish security forces caused the deaths of 2,00o people. The Turkish State regularly deployed war planes during this time in order to regain control in this region. ${ }^{145}$ This disproportionate use of force against PKK youth militia in densely populated Kurdish areas during the curfew period was also detailed by the Office of the United Nations High Commissioner for Human Rights ('OHCHR'), including the indiscriminate shelling of cities with heavy artillery, tanks and air-dropped munitions. ${ }^{146}$

The unprecedented eruption of fighting between the PKK's militants and the Turkish security forces in the urban district of south-eastern Turkey during the curfew, was followed by a gradual of shift of violence into rural areas from the middle of 2016. As confirmed by the International Crisis Group, the Turkish security forces carried out the most intense and the longest military operations in years against the PKK militants in the provinces of Diyarbakir by deploying approximately 7,000 soldiers in March 2017. ${ }^{147}$ In the same time period, the clashes between both sides had also gradually increased in other provinces of the south-eastern Turkey such as Hakkari, Botan, Mardin Dersim, Agri and Bitlis. ${ }^{148}$ The International Crisis Group report also noted that between May and September 2019, the Turkish army launched at least 76 cross-border air operations against the PKK in and around its headquarters, in the Qandil Mountain. It confirmed that go PKK members and 11 Turkish soldiers were lost their life as the result of these fatalities. ${ }^{149}$ The PKK has also further systematised its attacks against the State security forces in the rural area of the Kurdish region since 2016. For example, in March 202O, the PKK conducted a largescale operation against the Turkish army in the province of Agri and killed 79 Turkish soldiers. ${ }^{150}$

The PKK attacks are not restricted in the Kurdish region. The PKK has managed to carry out military actions in every part of Turkey. For example, on 7 December 2009, its militants attacked Turkish defence forces and killed seven

\footnotetext{
144 OHCHR (n 102) [20].

145 OHCHR (n 102) [20]; SendikaOrg, 'Tsk'ya bağlı savaş uçakları Nusaybin'i bombaladı' (24 May 2016); 'Nusaybin ilk kez savaş uçakları tarafından bombalandı' ( $A N F, 12$ May 2016).

146 онCHR (n 102) [20].

147 International Crisis Group, 'Assessing the Fatalities in Turkey's PKK Conflict' (22 October 2019) <www.crisisgroup.org/europe-central-asia/western-europemediterranean/turkey/ assessing-fatalities-turkeys-pkk-conflict>.

148 Y Okur and C Asan, 'PKK'nin dogu grubuna agir darbe' (Anadolu Agency, 27 September 2018) <www.aa.com.tr/tr/turkiye/pkknin-dogu-grubuna-agir-darbe/1266262>.

149 International Crisis Group (n 147).

150 'HPG: 79 soldiers killed in revolutionary operation in Ağrn' (ANF, 9 March 2020) <anfenglish.com/news/hpg-79-soldiers-killed-in-revolutionary-operation-in-agri-42181>.
} 
of them in Tokat in the Black Sea region, which is one of the farthest places from the Kurdish region. ${ }^{151}$ Another example was the abduction of 20 members of the Turkish intelligence service, including the director and human resources director of the Turkish intelligence service, by the HPG forces in Northern Iraq on 4 August 2017..$^{152}$ This highlights the ability of the PKK to determine a unified military strategy and coordinate and conduct large scale military operations against Turkish security forces across Turkey and also in foreign States.

The resistance of the PKK and its success against the Turkish security forces, the second largest NATO army, ${ }^{153}$ which have spent $\$ 450$ million dollars in the fight with the $\mathrm{PKK},{ }^{154}$ further signifies that the PKK has a certain degree of organisation which has enabled it to plan and sustain a military confrontation over a protracted period. The high intensity of the war, which sometimes involved half of the Turkish land forces ${ }^{155}$ and cost the lives of more than 40,0oo people, ${ }^{156}$ including the destruction of 3,215 Kurdish settlements ${ }^{157}$ and forcible displacement of around 4 million Kurds from 1984 to 2001, remains ongoing. ${ }^{158}$ For example, according to the OHCHR at least 2,Ooo deaths ${ }^{159}$ and total destruction of more than 24,000 buildings occurred during the curfew period..$^{160}$

151 'Tokat'ta Jandarmaya Saldiri: 7 Sehit' (CNNTurk, 12 July 2009) <www.cnnturk.com/20o9/ turkiye/12/o7/tokatta.jandarmaya.saldiri.7.sehit/554485.o/index.html>. 'MIT administrators arrested by the PKK speak' (ANFNews, 6 January 2018) <anfenglishmobile.com/news/mit-administrators-arrested-by-the-pkk-speak-24056>. 'NATO's second biggest army just bought nearly £2 bn of weapons from Russia' (Independent, 12 September 2017) <www.independent.co.uk/news/world/europe/natoarmy-buys-2-billion-dollars-weapons-from-russia-military-deal-a7942521.html>.

Y Akdogan, Insaniyasat ki devlet yasasin: democratik acilim surecinde yasananlar (Meydan 2010) 15 .

155 Ozdag (n 91) 39; Jongerden (n 91) 61-63.

156140 Journos, 'Sayilarla 1984'ten bu yana PKK ile catismadaki olumler' (24 March 2017) <14ojournos.com/sayilarla-1984ten-bu-yana-pkk-ile-catismalardaki-olumler5ce123d214be>; Yildiz \& Breau (n 21) 16.

O Oyan et al, Doğu ve Güneydoğu Anadolu Bölgesi Köye Dönüş ve Rehabilitasyon Projesi Alt Bölge Gelişme Planı (Bölge Kalkınma İdaresi (B KI) - Türk Sosyal Bilimler Derneği 2001) 1-7; K Yildiz and C Hughes, Internally Displaced Persons: The Kurds in Turkey (K HRP/GöçDer/Insan Haklan Dernegi 2003) appendix II; K Yildiz, The Kurds in Turkey (Pluto Press 2005) 7 .

158 Turk Insan Haklari Vakfi ('TI HV'), Turkiye Insan Haklari Raporu (1991, 1992, 1993, 1994, 1995) $5^{2-3}$, 109, 10, 16, 62, 103, 130, 149, 130, 140, 161, 19, 71, 149, 223, 259, 267 respectively; Yildiz \& Hughes (n 157) appendix II; Turkiye Buyuk Millet Meclisi Insan Haklarini Inceleme Komisyonu, Terror ve Siddet Olaylari Kapsaminda Yasam Hakki Ihlallerini Inceleme Raporu (24 Donem, 3. Yasama, Yili 2013) 64, 74. OHCHR (n 102) [2].

160 Union of Chambers of Turkish Engineers and Architecture, '2015-2016 Destroyed Cities Report' (2016) <www.dimod.org.tr/sur/english.pdf>. 
To conclude, the capacity of the PKK to plan and coordinate more than 100,000 large scale military operations in accordance with the State statistics $^{161}$ over 37 years, leaves no doubt that the PKK has fulfilled the requirement intensity of violence under $\mathrm{CA}_{3}$.

\subsubsection{The Ability to Comply with the Law of Armed Conflict}

$\mathrm{CA}_{3}$ requires that the non-State armed group must have the necessary organisational ability to ensure respect for fundamental humanitarian norms of IHL in all activities. ${ }^{162}$ This obligation does not require actual implementation and compliance with the law but rather, as stated by the Boškoski Trial Chamber, 'the organisational ability [of non-State armed group] to comply with the obligations of international humanitarian law' ${ }^{163}$ would be decisive. International tribunals and scholars have underlined that non-international armed groups can only reach the requisite threshold of respect for minimum IHL's obligations provided they have certain level of the discipline within themselves which obliges 'the practice of training people to obey rules or code of behaviour [and] using punishment to correct disobediences.'. ${ }^{164}$ The Boškoski Trial Chamber has found indicators such as the existence of regulations or codes of conduct; military and ideological training of group members; the existence of disciplinary mechanisms or inflict punishment to ensure discipline within the group and respect for IHL. ${ }^{165}$

The PKK has explicit and clear rules, training and orders as well as an effective sanction system which ensures its members respect its rules. The РКK Central Committee issues rules and orders, and its hierarchal chain of command ensures that its members follow and enforce the rules within the group. The PKK disciplinary system is governed and enforced through its disciplinary committee. Those members who break the rules can be subjected to an 'oral reprimand'; a 'written critique'; 'detention'; 'complete isolation from the group

\footnotetext{
161 Memurlar.net, '33 yilda 16 bin 500 sehit verdik' (23 May 2017) <www.memurlar.net/ haber/6696oo/33-yilda-16-bin-5oo-sehit-verdik.html>.

$162 \mathrm{CA}_{3}$ states that: 'In the case of armed conflict not of an international character occurring in the territory of one of the High Contracting Parties, each Party of the conflict shall be bound to apply, as a minimum, the following provisions.... See also Prosecutor v Boskoski and Tarculovski (n 36) [205].

163 Prosecutorv Boskoski and Tarculovski (n 36) [205].

164 Oxford Dictionary (online), definition of 'discipline' <www.oxfordlearnersdictionaries. com/definition/english/discipline_1?q=discipline>; Rodenhauser (n 79) 87; ICRC, 'International Humanitarian Law and the Challenges of Contemporary Armed Conflicts' (ICRC 2003) 228; Prosecutorv Limaj (n 77) [116]-[117]; Prosecutorv Boskoski and Tarculovski (n 36) [274].

165 Prosecutorv Boskoski and Tarculovski (n 36) [202].
} 
and being subjected to an individual theoretical education'; and 'handing over his/her weapon and working in non-military services.'166 If the disciplinary committee thinks that the member of the group has committed a gross violation of the rules, it can refer the case to the military court which can then order to 'dismiss the person from his/her duty', to 'suspend the membership of the person', or to 'expel them' from the РКк.167

The PKK is not a State as defined by international law and therefore cannot sign international treaties, but it adopted a system of discipline to ensure that its members respect international humanitarian law. ${ }^{168}$ The PKK and ARG$\mathrm{K} / \mathrm{HPG}$ have adopted regulations and codes of conduct including rules governing warfare and humanitarian law and have declared adherence to a number of international conventions. In 1995, the PKK officially communicated with the Swiss government and explicitly declared its political commitment to observe the Geneva Conventions and signed an agreement with Geneva Call, a Swiss-based non-governmental organisation, in order to formalize its commitment. ${ }^{169}$ This is confirmed by a statement to the United Nations which states:

In its conflict with the Turkish state forces, the PKK undertakes to respect the Geneva Conventions of 1949 and the First Protocol of 1977 regarding the conduct of hostilities and protection of the victims of war and to treat those obligations as having the force of law within its own forces and the areas within its control. ${ }^{170}$

The PKK's compliance with some of the fundamental humanitarian norms of IHL has been confirmed by both independent international monitoring institutions and domestic human rights organisations. A report by the Turkish Human Rights Association ('IHD') confirms that the PKK complied with the Geneva Conventions, especially on the rights and treatment of prisoners of war, even prior to its official commitment. According to the report, the PKK abducted 335 members of the security forces between 1990 and 2012, some of whom were imprisoned for two years. Hostages were considered war prisoners and treated as such under the Third Geneva Convention, with the provision

\footnotetext{
166 PKK, PKK 5. Kongre Kararlari (Weşanên Serxwebûn 1995) 189-195.

167 ibid $185^{-7}, 196-203$.

168 Kurdistan Workers' Party ('PKK') (n 123).

169 Bianet, 'Kongra Gel: Turkiye adim atsin' (2 June 2004) < bianet.org/bianet/print/35885kongra-gel-turkiye-adim-atsin $>$; Istibaharatsahasi, 'РКK Sempatizani Siteden Cenevre Sozlesmesi' (11 December 2013) <istihbaratsahasi.wordpress.com/2012/12/11/ pkk-sempatizani-siteden-cenevre-sozlesmesi/>. 
of medical assistance to wounded soldiers, food and family visits. ${ }^{111}$ The IHD report confirms the PKK has released all hostages and handed them over to either ICRC members or domestic human rights organisations. The individual accounts of some of these hostages confirm what is stated in the report. ${ }^{172}$ This shows an ability of the PKK to comply with the fundamental guarantees for the protection and care of persons deprived of their liberty and to treat prisoners humanely contained in Article 1(a), (b) and (c) of $\mathrm{CA}_{3}$, which also constituted CIL even before its declaration of official commitment to respect IHL. ${ }^{173}$ In addition, in 2006 the PKK signed the Convention on the Prohibition of the Use, Stockpiling, Production and Transfer of Anti-Personnel Mines and on their Destruction ('Anti-Personnel Mine Convention'), and made a commitment to protect children in armed conflict in October 2013. ${ }^{14}$

The monitoring procedure of Geneva Call, which is an independent international organisation, reveals that the PKK complied with both commitments in practice. ${ }^{175}$ In relation to allegations by the Turkish government that the PKK has planted anti-personnel mines, Geneva Call has repeatedly called on both Turkey and the PKK to conduct missions of verification and noted that 'this [request] was always ignored by [Turkish] authorities whereas the PKK welcomed the offer.'176 This highlights the professed intention and ability of the PKK to comply with the Anti-Personal Mine Convention, as its scope extended to NIAC s. ${ }^{177}$ Likewise, the PKK invited Geneva Call to monitor its commitment

171 Insan Haklari Dernegi ('IHD'), '1990-2012 PKK Tarafindan Alikonunalar Rapor' (9 May 2013) <www.ihd.org.tr/199o-2012-pkk-mltanlari-tarafindan-alikonulanlar-rapor/> .

172 Esiraskerhakki, 'Ilk Esir Alma Olayi/Yener Soylu' <esiraskerhakki.wordpress.com/ esir-asker-kronolojisi/ilk-esir-alma-olayiyener-soylu/>.

173 The same could be claimed in respect of AP II, as this Protocol establishes fundamental guarantees for the protection of individuals (see, for example, AP II art 4) as well as protection and care for persons deprived of their liberty (see AP II art 7).

174 Geneva Call, 'Turkey: the Kongra Gel/HPG - also known as Kurdistan Workers' Party - pledges to renounce the use of anti-personal mines' (18 July 2006) < genevacall.org/ turkey-kongra-gelhpg-also-known-kurdistan-workers-party-pkk-pledges-renounce-useanti-personnel-mines/>; Geneva Call, 'Turkey'<genevacall.org/country-page/turkey/>.

Geneva Call, 'Turkey: Monitoring the HPG/PKK's prohibition on using children in hostilities' (25 July 2015) <genevacall.org/turkey-monitoring-hpgpkks-prohibition-usingchildren-hostilities/>; Geneva Call, 'New allegations on mine use by the Turkish armed forces suggest that independent verification missions are imperative' (19 April 2010) <genevacall.org/new-allegations-mine-use-turkish-armed-forces-suggests-independentverification-missions-imperative/.

176 Geneva Call, 'New allegations on mine use by the Turkish armed forces' ( $\mathrm{n}$ 175).

177 United Nations, 'Convention on Prohibitions or Restrictions on the Use of Certain Conventional Weapons which May be Deemed be Excessively Injurious or to Have Indiscriminate Effects, Final Document, Part II' (1996) ccw/CONF.I/16; see also M J Matheson, 'The Revision of the Mines Protocol' (1997) 91 AJIL 158, 159. 
to the protection of children in armed conflict. Geneva Call observed that the PKK has sent children under 18 back home where they would not be subjected to persecution by the State. Those children of between 16 and 18 who have remained on a voluntary basis have been separated from military units and 'were receiving an education on subjects such as geography or mathematics, and ... were kept far from any military activities.' ${ }^{178}$ This further demonstrates PKK commitment to comply with the wording of Article 4(3)(c) of the Protocol and its prohibition of recruitment of children under the age of 15 , also a CIL rule.

There is sufficient evidence of a declared intention and practice of the $\mathrm{PKK}$ working to comply with fundamental humanitarian norms contained in $\mathrm{CA}_{3}$ and the above-mentioned rules of customary IHL. This includes by way of public prosecutions for breaches of IHL. For example, on 1 August 2010, four civilians were killed in Batman (in south-eastern Turkey) as the result of a mine expulsion. Shortly after the incident, the HPG General Staff brought an action against two of its members for their involvement in the incident to the HPG Military Court. On 30 November 2010, the Court found that the mine led to the death of four civilians by the defendants. It considered this practice a violation of 'the PKK international obligation under the Anti-Personnel Mine Convention which has been incorporated in HPG domestic law through the HPG fourth conference.' Therefore, the Court found the defendants guilty and imposed sentences of 20 and 24 years' imprisonment respectively for each defendant. It also ordered the HPG's Commander-in-Chief to give a public apology to the victims' families. ${ }^{179}$

\subsubsection{The Requirement to Exercise Control Over Territory}

There are two schools of thought with regards to whether the requirement to exercise some degree of territorial control by an organised non-State armed group is necessary for the purposes of a NIAC according to $\mathrm{CA}_{3}$. On the one hand, it has been argued that an organised armed group must exercise control over 'some part of the national territory' in order to carry out its obligations under $\mathrm{CA}_{3} \cdot{ }^{180} \mathrm{On}$ the other hand, a number of influential bodies have declared that the territorial control requirement 'is not at all determinative'. In support of the latter view, Tilmann Rodenhauser argues that 'neither the wording of Common Article 3 nor its context require' control over territory by a non-State

\footnotetext{
178 Geneva Call, 'Turkey: Monitoring the HPG/PKK's prohibition on using children in hostilities' (n 175).

179 'HPG'den Batman davasinda agir mahkumiyet' (ANF, 30 November 2010).

180 G I A Draper, 'The Geneva Conventions of 1949' (1965) 114 Recueil des Cours 90.
} 
armed group as a necessary criterion in assessing the existence of a non-State party to a NIAC. ${ }^{181}$ According to Sivakumaran the root of this confusion might arise from citing the ICRC Commentaries on $\mathrm{CA}_{3}$, which contain a compilation of proposals made at the 1949 Diplomatic Conference that include the requirement of territorial control, as an authority for the existence of a NIAC under $\mathrm{CA}_{3} \cdot{ }^{182}$ Those scholars who object to the requirement of territorial control in the context of $\mathrm{CA}_{3}$ persuasively claim that a degree of territorial control on the part of non-State armed groups would certainly be useful evidence in determining that a NIAC is taking place. This is because control over territory by the organised armed group would further strengthen the case of the organisation of the group, its ability to plan and carry out protracted armed attacks, and to fulfil certain humanitarian obligations. ${ }^{183}$ Conversely, the absence of control over territory by a non-State armed group does not preclude the existence of a NIAC in the context of $\mathrm{CA}_{3}$, whereas it would prevent the application of AP II. ${ }^{184}$ Even the threshold of an explicit requirement of territorial control contained in Article 1 of AP II should not be interpreted as requiring a government-like control over a part of territory. As such, strict interpretation would 'severely limit the [the Protocol's] real significance and usefulness' in taking into account the nature of guerrilla warfare. ${ }^{185}$ The requirement can be made providing the organised armed group has undermined territorial control by the government 'without necessarily exercising complete or continuous control over an area.'186 Control over a 'modest area of land' that escaped 'the control of government forces' might be sufficient. Indeed, the International Commission of Inquiry on Darfur endorsed this view by noting that 'certain rural areas' over which 'control [is] not fixed' by 'mobile guerrilla group[s]' is sufficient for the purpose of the Protocol. ${ }^{187}$

The above analysis demonstrates that the notion of territorial control is one of the possible indicators of the NIAC, but it is not required for the existence of a NIAC in the context of CA3. Despite this fact, this section examines how far the PKK has fulfilled the requested requirement of territorial control in order

\footnotetext{
$181 \quad$ Rodenhause (n 79) 43 .

182 Sivakumaran (n 3o) 181.

183 ibid; Moir (n 75) [41]; Rodenhause (n 79) 43.

184 ibid.

185 Official Records (n 10) vol viII, 235 (Egypt); Rodenhause (n 79) 50; Sivakumaran (n 30) 185.

186 Moir (n 2) 106; Georges Abi-Saab, 'Wars of National Liberation in the Geneva Conventions and Protocols' (1979) 165 Recueil des Cours 353, 410-411; Official Records (n 10) vol viI, CDDH/sR.49, 410-411; Official Records (n 10) vol —, 67, 70.

187 UNSC, 'Report of the International Commission of Inquiry on Darfur to the SecretaryGeneral' (2005) UN Doc S/2005/6o (1 February 2005) [132].
} 
to further prove that the PKK possesses certain levels of organisation which makes it capable of not only planning and carrying out 'protracted violence', but also respecting humanitarian rules and principles. The PKK had effective territorial control of rural areas in the Kurdish region from 1984 until 1993. Half of the Kurdish provinces were declared 'semi-liberated zones' by the PKK where the security forces were unable to remain in control and enter for longer periods of time. ${ }^{188}$ During this time, State authority almost disappeared in the region and State institutions were replaced by the PKK's parallel institutions such as courts and schools. ${ }^{189}$

The PKK has continued to exercise strict regular control over certain rural areas in south-eastern Turkey since 1993, but due to its operation as a mobile guerrilla group, these areas of control are not fixed. Despite withdrawing its forces outside Turkish State territory for five years between 1 September 1999 and 1 June 2004, it nevertheless was capable of regaining territorial control of many of those rural areas since the peace process collapsed in 2004. ${ }^{190}$ The PKK has divided south-eastern Turkey into nine regions and spread its groups within these regions, each of which has a geographical 'safe haven'. For example, it is reported that the PKK has at least nine camps in the Botan region alone. ${ }^{191}$ The PKK use these safe havens to provide ideological and military training to its members; to regroup after battles; store weapons and supplies; to imprison those abducted by them; and to plan and coordinate their operations. ${ }^{192}$

In addition, the PKK has strictly re-implemented its strategy of holding territory in certain parts of the Kurdish region after the re-collapse of peace talks with the Turkish State in 2012. ${ }^{193}$ Between July and September 2012, it declared a $35 \mathrm{~km}$ liberated zone within Turkish territory and covering two Kurdish cities. It set up checkpoints, and journalists and observers were required to have

188 U Ozdag (n 91) 39; J Jongerden (n 91) 6o-63; A Manes, Profiles in Terror: The Guide to Middle East Terrorist Organisation (Rowman \& Littlefield 2004) 181; Marcus (n 88) 4; Yazici (n 127) $115-529$.

U Ozdag (n 91) 39; J Jongerden (n 91) 6o-63; J van Etten et al, 'Environmental destruction as a counterinsurgency strategy in the Kurdistan region of Turkey' (2008) Geoforum 3, 3-4; J Jongerden, 'Village Evacuation and Reconstruction in Kurdistan (1993-2002)' (2010) 186 Etudes 77, 82-84.

ATakan, 'PKK'nin Kongre Tarihi' (Yenicag, 26 March 2015); M Ince, 'PKK'nin hangi kampi ne ise yariyor' (Aydinlik, 26 May 2019); HaberTurk, 'Iste PKK'nin barindigi kamplar' (12 November 2007); U Ozdag, 'Terörle mücadele konusunda sorular' (Yenicag, 23 June 2012). Semdinli Haber, 'Tarihi çekilme yarın' (7 May 2013); Hurriyet, 'İtirafçı, PKK kamplarının haritasını Verdi' (28 December 2007); Vatan, 'Türkiye'yi 12 parçaya ayırdılar!' (12 November 2012).

192 Yazici (n 127) 496; Hurriyet (n 191); Ince (n 19o).

193 'Interview with Murat Karayilan' (Firat News Agency, 3 August 2012). 
permission from the HPG's members in order to enter this area. ${ }^{194}$ Between August 2015 and April 2016, the YPs erected barricades, dug trenches and held 10 Kurdish cities and 39 towns, which declared democratic self-governance after the collapse of the peace process, and denied government incursion into these self-governance areas despite offensive tactics by the Turkish security forces. As a result, the State security forces could only partly regain control of these places after a year. ${ }^{195} \mathrm{In}$ parallel to the shift of violence from urbans areas to rural areas since April 2016, the PKK militants also expanded their territorial control strategy in the rural areas of south-eastern Turkey. The Turkish media reported that the PKK established many mini Qandils (the PKK headquarters) within Turkish territory, ${ }^{196}$ some of which have fully-equipped hospitals. Finally, the establishment of the 'Medya defence areas' within the borders of Iran-Iraq and Turkey, containing more than 600 villages and 23 camps on 150 hectares since 2006, ${ }^{197}$ further confirms that the PKK has satisfied the restrictive territorial control criterion required by AP II.

\section{4}

\section{Conclusion}

The above examination demonstrates that the PKK struggle is not a guerrilla war of sporadic attacks and that the conflict does not consist of limited insurgency or isolated and sporadic violence or terrorist attacks, but is a prolonged violent armed conflict with a certain intensity, over a widespread and expanding geographic area for a period of more than three decades.. The goal of the PKK is not to instil fear in a population or terrorise civilians. Rather, through its armed campaign, the PKK has consistently maintained its aim of liberating Kurdish people from subjugation by an oppressive State infrastructure which denied recognition of Kurds and Kurdish political participation and representation. The PKK initially intended to establish an independent Kurdish

194 'Karayilan: Sinirin Otesi Berisi Hikaye Oldu' (ANF, 3 August 2012) <anfturkce.com/ guncel/karayylan-synyryn-otesi-berisi-hikaye-oldu-6o66>; Turkiye, 'Gulten ve Aysel'den Kucaklasma Aciklamasi' (2O August 2012) <www.turkiyegazetesi.com.tr/gundem/20754. aspx $>$.

195 онснг (n 102) [2]; 'Ozyonetim ilan edilen merkez sayisi 16'ya yuksledi' (T24, 20 August 2015) <t24.com.tr/haber/oz-yonetim-ilan-edilen-merkez-sayisi-16ya-yukseldi,3o6949>.

196 Milliyet, 'Küçük Kandil'e büyük darbe' (9 January 2017); Yenicag, 'PKK'nın yeraltı hastanesi şok etti!' (19 February 2016); Yeni Safak, 'Kü̧̈ük Kandil yok ediliyor!' (3o May 2017).

197 Z A Aydin, 'PKK'nin yeni Bekaa'si' (Sabah, 26 February 20o6); Milliyet, 'Kuzey Irak'ta 658 koy PKK'nin Kontolunde' (13 April 2016). 
State, a goal revised in 2000 as the focus turned to a Democratic Confederalist model within the territory of the Turkish State. Considering that violence took place within a sovereign State and with the involvement of thousands of military members, and that the PKK fulfilled the three main essential criteria and the additional control over territory criterion for determining the existence of a NIAC under $\mathrm{CA}_{3}$, it can be concluded that the Kurdish conflict in Turkey constitutes a NIAC within the meaning of both $\mathrm{CA}_{3}$ and CIL. However, this does not prevent the Turkish government from continuing to treat the PKK as a criminal organisation given that the provisions of the $\mathrm{CA}_{3}$ do not affect the legal status of the parties to the conflict. Nonetheless, in international law the two sides to the conflict should be adhering to the same rules in respect of the conduct of hostilities. The protection of civilians and combatants depends on application and respect for the fundamental, customary norms of IHL. 